\title{
Analisis SWOT untuk Mengetahui Positioning Perusahaan dalam Menentukan Strategi Perusahaan PT. Piramid Mas Perdana Divisi Airport Sidoarjo
}

\author{
*Dicky Zulyanzah Santoso, Pribadiyono, Diana Rapitasri \\ Program Studi Manajemen Fakultas Ekonomi dan Bisnis \\ Universitas Bhayangkara Surabaya, Indonesia
}

DOI: 10.46821/benchmark.v1i2.147

\begin{abstract}
Abstrak
Penelitian dengan judul “Analisis SWOT Untuk Mengetahui PositioningPerusahaan Dalam Menentukan Strategi Perusahaan Pada PT. Piramid Mas Perdana Divisi Airport Sidoarjo, ini dibuat dengan mempertimbangkan semakin meningkatnya intensitas persaingan yang terjadi dalam bisnis perindustrian. Melalui analisis SWOT perusahaan mampu melihat kondisi bisnisnya secara keseluruhan. PT. Piramid Mas Perdana Divisi Airport Sidoarjo berada dikuadran I, posisi ini menandakan yang kuat dan berpeluang maka strategi yang harus diterapkan adalah SO: Meningkatkan kualitas produk agar lebih memuaskan pelanggan, Mempertahankan kesesuaian harga yang diharapkan pelanggan, Memberikan pelayanan dan hasil yang memuaskan, Meningktakan sistem pemasaran yang lebih luas. Adapun strategi bersaing menggunakan Matrik Internal-Eksternal yaitu: Menciptakan pelayanan yang lebih baik agar dapat memuaskan pelanggan, Menjaga kualitas produk agar citra baik perusahaan tetap terjaga, Memanfaatkan teknologi modern, Memanfaatkan teknologi modern, Memberikan harga yang terjangkau dengan kualitas prodak yang baik, Meningkatkan sistem pemasaran yang lebih luas.
\end{abstract}

Kata kunci: Analisis SWOT, Positioning, Strategi yang Akan Datang PT. Piramid Mas Perdana Divisi Airport Sidoarjo

\begin{abstract}
Research with the title "SWOT Analysis to Know Company Positioning in Determining Company Strategy at PT. Piramid Mas Perdana Sidoarjo Airport Division, was made by considering the increasing intensity of competition that occurs in the industrial business. Through a SWOT analysis the company is able to see the overall business condition. PT. Piramid Mas Perdana Sidoarjo Airport Division is in quadrant I, this position signifies a strong and likely opportunity, the strategy that must be implemented is SO: Improve product quality to better satisfy customers, Maintain the suitability of prices expected by customers, Provide services and satisfying results, Improve broader marketing system. The competitive strategy uses the InternalExternal Matrix, namely: Creating better services in order to satisfy customers, Maintaining product quality so that the company's good image is maintained, Utilizing modern technology, Utilizing modern technology, Providing affordable prices with good product quality, Improving the system broader marketing.
\end{abstract}

Keywords: SWOT Analysis, Positioning, Future Strategies of PT. Piramid Mas Perdana Sidoarjo Airport Division.

*Corresponding Author:

Hal: 95-104

Email: dickyzulyanzahsantoso@gmail.com 
Sumber daya manusia (SDM) yang berkualitas sangat dibutuhkan dalam era globalisasi karenanya setiap perusahaan berlomba-lomba menciptakan SDM yang berkualitas. Globalisasi berpengaruh cukup besar terhadap empat sektor ekonomi di Indonesia yaitu pada sektor ekspor, impor, investasi dan tenaga kerja. Untuk menghadapi persaingan pada sektor-sektor tersebut, perusahaan seharusnya memiliki keunggulan-keunggulan dibandingkan dengan pesaingnya khususnya pada SDM yang dapat diandalkan. SDMyang unggul menentukan keberhasilan dan kemajuan dari suatu perusahaan. Demikian pula kemajuan teknologi, perkembangan informasi, tersedianya modal dan bahan yang memadai, apabila tidak diimbangi dengan SDM yang ahli pada bidangnya akan memberikan hambatan bagi perusahaan dalam mencapai tujuannya. Oleh sebab itu, SDM harus menjadi pribadi-pribadi yang mau belajar dan bekerja keras dengan penuh semangat, sehingga potensi setiap individu mampu berkembang dengan maksimal. Adapun untuk menghadapi persaingan global, perusahaan harus memiliki sumber daya yang tangguh. Hal ini disebabkan karena globalisasi mampu mengubah pola para pelaku ekonomi dalam proses produksi, perubahan struktural ekonomi, dan kebijakan ekonomi pemerintah. Globalisasi menyebabkan SDM untuk dapat menyesuaikan kemampuannya pada perkembangan-perkembangan yang terjadi pada berbagai bidang.

Dunia industri mesin dan listrik pada sektor penerbangan di Indonesia mengalami perkembangan yang cukup pesat. Hal ini dibuktikan dengan kenaikan jumlah lalu lintas udara, baik penumpang maupaun arus barang. Olehnya dibutuhkan SDM dan sumber daya teknologi yang berintegrasi satu sama lain. Salah satu alat pelayanan yang ada di bandara dan dibutuhkan oleh pihak bandara serta konsumen adalah alat conveyor. PT. Piramid Mas Perdana Divisi Airport ini merupakan salah satu perusahaan yang memproduksi alat conveyor dan produknya telah memiliki nilai kegunaan bagi para konsumennya.Pada tahun 2014 pemerintah mulai gencar membangun infrastruktur dimana di dalamnya termasuk bandara-bandara, permintaan akan conveyor bagasi meningkat tajam. Diputuskan pada tahun itu dibutuhkan satu divisi tersendiri untuk fokus melayani pasar ini. Jadi sampai saat ini divisi bandara (Airport) di PT. Piramid Mas Perdana kurang lebih sudah berjalan selama 5 tahun.

\section{TINJAUAN PUSTAKA}

\section{Manajemen Sumber Daya Manusia}

Menurut Sedarmayanti (2017:3), Manajemen Sumber Daya Manusia merupakan suatu proses pemanfaatkan SDM secara efektif dan efisien melalui kegiatan perencanaan, penggerakan, dan pengendalian semua nilai yang menjadi kekuatan manusia untuk mencapai tujuan.

\section{Manajemen Strategi}

Menurut Isniati (2019:3), manajemen strategi adalah proses perencanaan, implementasi, serta pengandalian satu strategi organisasi dan juga menentukan misi dan tujuan organisasi tersebut yang berkaitan dengan lingkungan eksternalnya.

\section{Matris SWOT}

Menurut Freddy Rangkuti (2015:20) Analisis SWOT adalah identifikasi berbagai faktor secara sistematis untuk merumuskan strategi perusahaan yang digunakan untuk 
mengevaluasi Strenghs, Weaknesses, Opportunities, Threats dalam suatu proyek atau usaha.

\section{Kerangka Konseptual}

berikut ini dikemukakan suatu kerangka konseptual berupa desain penelitian yang berfungsi sebagai penuntun untuk memudahkan dan memahami alur berpikir dalam penelitian ini (Gambar 1).

\section{METODE PENELITIAN}

Menurut Sugiyono (2017:09), menyatakan bahwa metode ini digunakan untuk meneliti pada kondisi obyek yang alamiah, (sebagai lawannya adalah eksperimen) dimana peneliti adalah sebagai instrumen kunci, teknik pengumpulan data dilakukan secara triangulasi (gabungan), analisis data bersifat induktif/kualitatif, dan hasil penelitian kualitatif lebih menekankan makna dari pada generalisasi.

\section{Jenis Data}

Teknik pengumpulan data menjelaskan tentang bagaimana data dikumpulkan sebelum diolah. Berdasarkan sumbernya, jenis data dibagi menjadi dua yaitu :

\section{a. Data Primer}

Yaitu data yang dibuat oleh peneliti untuk maksud khusus menyelesaikan permasalahan yang sedang ditanganinya. Data dikumpulkan sendiri oleh peneliti langsung dari sumber pertama atau tempat objek penelitian dilakukan.

b. Data Skunder

Yaitu data yang telah dikumpulkan untuk maksud selain menyelesaikan masalah yang dihadapi. Dalam adaanya penelitian ini menjadi sumber data skunder adalah data perusahaan yang ada berkenaan dengan penelitian yang dilakukan.

\section{Sumber Data}

a. Hasil wawancara dan pengisian kuesioner kepada pimpinan dan berbagai karyawan PT.Piramid Mas Perdana Divisi Airport Sidoarjo Sejumlah 10 orang. Hasil kuesioner diperoleh dari hasil karyawan yang bekerja di PT.Piramid Mas Perdana Divisi Airport Sidoarjo sesuai dengan kondisi responden secara individu, baik lakilaki maupun perempuan.

b. Dokuemen-dokumen yang terdapat diperusahaan, seperti sejarah perusahaan, visi dan misi, serta struktur organisasi perusahaan.

c. Buku-buku referensi pendukung untuk melengkapi penelitian mengenai Analisis SWOT untuk merencanakan strategi perusahaan.

d. Jurnal atau skripsi terdahulu yang dapat menjadi bahan study pembanding dalam melakukan penelitian.

\section{Pengujian Data}

Pengujian hasil analisis dan dilakukan secara informasi (dalam bentuk naratif) dan formal (dalam bentuk table, grafik). Penyajian data dalam bentuk naratif untuk mengidentifikasi potensi yang ada sehingga diperoleh suatu gambaran lengkap dari permasalahan yang dibahas. Penyajian formal dilakukan untuk mendeskripsikan strategi perusahaan PT.Piramid Mas Perdana Divisi Airport Sidoarjo. 


\section{Teknis Analisis Data}

Analisis data bertujuan untuk menyederhanakan seluruh data yang terkumpul, menyajikan secara sistematik, kemudian mengolah, menafsirkan dan memaknai data tersebut. Analisis data merupakan upaya pemecahan permasalahan penelitian untuk memperoleh jawaban atas permasalahan yang diteliti. Permasalahan dalam penelitian ini akan dianalisis secara deskriptif kualitatif.

\section{HASIL ANALISIS DAN PEMBAHASAN}

\section{Data Hasil Kuisioner}

Data hasil kuesioner ini merupakan hasil dari pengolahan kuesioner yang telah di isi oleh reponden, yang telah dilakukan di PT. Piramid Mas Perdana Divisi Airport Sidoarjo.

\section{Luasan Matrik}

Dari hasil pengolahan tersebut data untuk mengetahui luas matrik dan piroritas strategi pada tabel 4.7, maka dengan diperolah hasil luas matrik tersebar pada kuadaran I dengan luas matrik 9,67 tapi perlu diperhatikan juga bahwa luas matrik pada IV memiliki luas matrik yang cukup diperhitungkan yaitu 6,77.

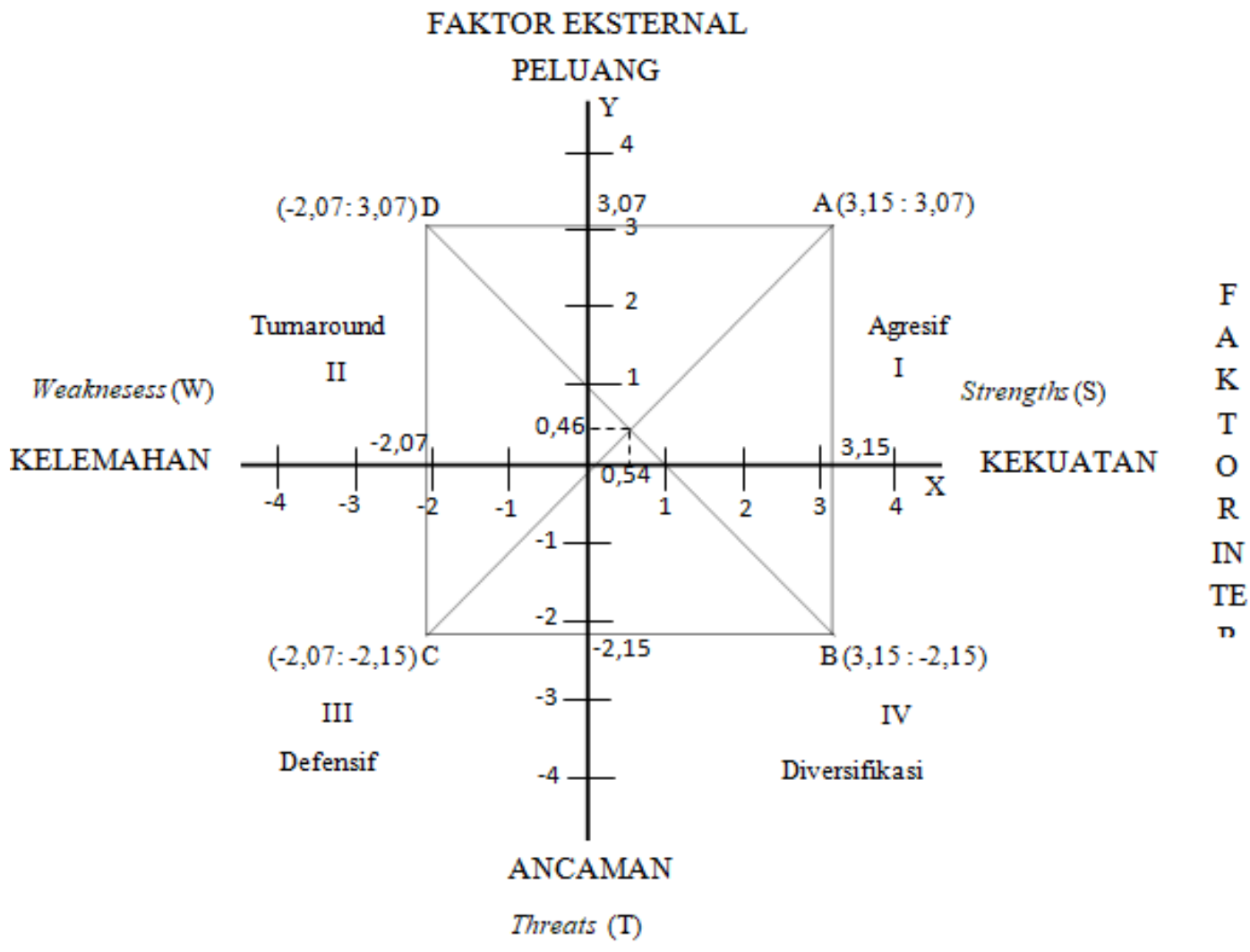

Sumber: Data Diolah, 2020

Gambar 1

Posisi PT. Piramid Mas Perdana Divisi Airport Sidoarjo dalam Diagram SWOT 
Tabel 1

Luasan Matrik dan Prioritas Strategi

\begin{tabular}{llccl}
\hline Kuadran & Posisi titik & Luasan Matrik & Rangking & Prioritas Strategi \\
\hline I & Titik A $(3,15: 3,07)$ & 9,67 & 1 & Agresif \\
II & Titik D $(-2,07: 3,07)$ & 6,35 & 3 & Trun Around \\
III & Titik C $(-2,07:-2,15)$ & 4,45 & 4 & Defensif \\
IV & Titik B $(3,15:-2,15)$ & 6,77 & 2 & Diversifikasi \\
\hline
\end{tabular}

Sumber: Data Diolah, 2020

Tabel 2

Faktor Internal

\begin{tabular}{lll}
\hline No & Faktor Strategi & Skor \\
\hline 1 & Faktor Kekuatan (Strenght) & 3,15 \\
2 & Faktor kelemahan (Weakness) & $-2,07$ \\
Total & & 1,08 \\
\hline
\end{tabular}

Sumber: Data Diolah, 2020

Tabel 3

Faktor Eksternal

\begin{tabular}{lll}
\hline No & Faktor Strategi & Skor \\
\hline 1 & Faktor Peluang (Opportunities) & 3,07 \\
2 & Faktor Ancaman (Threats) & $-2,15$ \\
Total & & 0,92 \\
\hline
\end{tabular}

Sumber: Data Diolah, 2020

\section{Data Evaluasi Faktor Internal}

Data ini merupakan hasil dari pengolahan kuesionar faktor internal (Strenght dan Weaknesses), maka dapat ditampilkan dalam tabel 2.

\section{Data Evaluasi Faktor Eksternal}

Data ini merupakan hasil dari pengolahan kuesioner faktor eksternal (Opportunities dan Threats), maka dapat ditampilkan dalam tabel 3 .

\section{Strategi untuk Manajemen yang Akan Datang}

PT. Piramid Mas Perdana Divisi Airport Sidoarjo didalam usahanya untuk masa yang akan datang antara lain :

a. Strategi Strenghts (S)

- Perusahaan diharapkan memperbaiki atau memperketat seleksi agar mendapatkan karyawan yang berkualitas.

- Perusahaan diharapkan meningkatkan kesejahteraan karyawan agar terciptanya loyalitas bagi karyawan untuk perusahaan.

- Perusahaan mengadakan evaluasi kinerja setiap bulan secara berkala untuk mengetahui kualitas kinerja karyawan.

- Perusahaan diharapkan menambah masa garansi yang lebih lama.

- Perusahaan diharapkan meningkatkan kualitas operasionalnya untuk menghadapi persaingan harga. 
b. Strategi Kelemahan (Weaknesses)

- Perusahaan diharapkan lebih meningkatkan jumlah hasil produksi agar bisa mencapai target yang ditentukan.

- Perusahaan diharapkan meningkatkan tingkat pendidikan karyawan agar setiap individu karyawan lebih berpotensi.

- Perusahaan diharapkan lebih melengkapi fasilitas perusahaan yang masih kurang agar memudahkan dalam menyelesaikan pekerjaanya.

- Perusahaan diharapkan memperluas pangsa pasar agar perusahaan bisa menghindari volume penjualan yang terkadang mengalami penurunan.

c. Strategi Peluang (Opportunities)

- Perusahaan diharapkan meningkatkan pelayanan yang berkualitas agar jumlah pelanggan tetap meningkat.

- Perusahaan diharapkan mampu menjalin kerja sama dengan pemerintahan agar keberlangsungan hidup perusahaan dapat terjamin.

- Perusahaan diharapkan mempertahankan hubungan baik dengan pelanggan agar untuk proyek selanjutnya berkerja sama kembali.

- Perusahaan diharapkan lebih untuk mengikuti perkembangan alat conveyor yang semakin canggih agar kualitas produk lebih unggul dari pesaing.

d. Strategi Ancaman (Threats)

- Perusahaan diharapkan merencanakan strategi yang lebih baik agar terhindar dari ancaman-ancaman terkait perusahaan serupa.

- Perusahaan diharapkan lebih mengontrol beban kerja yang diberikan kepada karyawan agar tidak menimbulkan kesetressan kerja.

- Perusahaan diharapkan lebih memiliki supplier cadangan agar dapat membandingkan harga dengan supplier lainya.

- Perusahaan diharapkan menyimpan bahan baku yang lebih untuk mengantisipasi adanya kenaikan harga akibat inflasi.

- Perusahaan diharapkan update dengan perkembangan tekologi sehingga tidak kalah dengan perusahaan pesaing.

- Perusahaan diharapkan memberi upah, insentif dan bonus kepada karyawan yang berprestasi agar karyawan memiliki motivasi yang lebih dalam menyelsaikan target yang diberikan perusahaan.

\section{SIMPULAN DAN SARAN}

Hasil Perihitungan Dengan Luasan Tiap Kuadran: Luasan pada kuadran I: Mempunyai rangking pertama dalam perhitungan luasan, kuadran ini adalah kuadran I sehingga perusahaan sebenarnya dalam posisi yang sangat menguntungkan karena perusahaan memiliki kekuatan yang cukup untuk memnfaatkan peluang tang tersedia. Saran - saran yang mungkin dapat kami berikan kepada PT.Piramid Mas Perdana Divisi Airport Sidoarjo dalam usahanya antara lain: Untuk Hasil Diagram SWOT, Walaupun posisi PT. Piramid Mas Perdana Divisi Airport Sidoarjo berada pada titik aman kuadran 1, perusahaan juga perlu memperhatikan segala kemungkinan yang dapat muncul secara tiba-tiba oleh kompetitor, adapun strategi yang sesuai untuk diterapkan adalah strategi SO. Untuk Hasil Matrik SWOT, didalam penerapan matrik SO, perusahaan sebaiknya 
terlebih dahulu melakukan evaluasi apakah kekuatan yang dimiliki perusahaan telah cukup untuk memanfaatkan pelung yang ada, dengan mempertahankan atau melakukan inovasi produk, kompetisi harga, memperluas pangsa pasar diluar pulau jawa. Untuk Hasil Matrik Internal-Eksternal, posisi perusahaan pada matrik Internal-Eksternal, yaitu berada didalam kolom GRWOTH and STABILITY, hal ini merupakan posisi yang baik untuk memulai berfikir ke depan mengenai penentuan strategi perusahaan ataupun langkah yang akan dicapai nantinya dengan strategi yang didapatkan. Adapun strategi bersaing antara lain : menambahkan varian produk dan inovasi teknologi lebih modern dan update informasi kesesuaian pelanggan.

\section{DAFTAR PUSTAKA}

Isniati, 2019, Manajemen Strategi : Intisari Konsep dan Teori, Penerbit, Andi, Yogyakarta.

Rengkuti Freddy, 2015, Teknik Membedah Kasus Bisnis, Penerbit, PT.Gramedia Pustaka Utama, Jakarta.

Sedarmayanti, 2017, Perencanaan Dan Pengembangan Sdm Untuk Meningkatkan Kompetensi, Kinerja, Dan Produktivitas Kerja, Penerbit, PT.Refika Aditama, Jakarta.

Sugiyono, 2017, Metode Penelitian Kuantitatif, Kualitatif, dan R\&D, Penerbit, PT. Alfabet, Bandung. 
Lampiran 1. Kuesioner Internal Faktor Analisis Strategi untuk Mengetahui Kekuatan (Strength)

\begin{tabular}{|c|c|c|c|c|}
\hline & Faktor Strategi & $\begin{array}{l}\text { Bobot } \\
\text { (B) }\end{array}$ & $\begin{array}{l}\text { Rating } \\
(\mathrm{R})\end{array}$ & $\begin{array}{c}\text { Skor } \\
(\mathrm{S}=\mathrm{B} \times \mathrm{R})\end{array}$ \\
\hline \multicolumn{5}{|c|}{ MSDM } \\
\hline 1. & Proses seleksi tenaga kerja yang berpotensi & 0,046 & 2,9 & 0,13 \\
\hline 2 & Kualitas tenaga kerja ahli & 0,044 & 2,9 & 0,13 \\
\hline 3 & Terjalinya komunikasi yang kondusif & 0,046 & 3,1 & 0,14 \\
\hline 4 & Adanya reward bagi karyawan berprestasi & 0,044 & 3,2 & 0,14 \\
\hline 5 & Adanya evaluasi karyawan setiap bulananya & 0,05 & 3,3 & 0,15 \\
\hline 6 & $\begin{array}{l}\text { Loyalitas kerja kepada perusahaan atau } \\
\text { organisasi }\end{array}$ & 0,048 & 3,1 & 0,17 \\
\hline 7 & Adanya pelatihan karyawan diperusahaan & 0,042 & 2,4 & 0,10 \\
\hline \multicolumn{5}{|c|}{ Operasional } \\
\hline 8 & $\begin{array}{l}\text { Terciptanya hubungan yang baik antara atasan } \\
\text { dengan bawahan }\end{array}$ & 0,04 & 3 & 0,12 \\
\hline & Memiliki standar kualitas operasioanlnya & 0,05 & 3,3 & 0,17 \\
\hline & $\begin{array}{l}\text { Kapasitas produksi lebih unggul diantara } \\
\text { pesaingnya }\end{array}$ & 0,042 & 3 & 0,13 \\
\hline & Adanya masa garansi & 0,048 & 2,9 & 0,14 \\
\hline & Pelayanan lebih cepat & 0,045 & 2,9 & 0,13 \\
\hline \multicolumn{5}{|c|}{ Fasilitas } \\
\hline 13 & Pencahayaan lampu yang baik & 0,045 & 2,7 & 0,12 \\
\hline & Kebersihan ruangan yang sangat baik & 0,046 & 3,5 & 0,16 \\
\hline & Kantor atau ruang kerja yang ber-AC & 0,044 & 2,9 & 0,13 \\
\hline \multicolumn{5}{|c|}{ Produk } \\
\hline 16 & Produk Kuat dan Tahan Lama & 0,045 & 3,1 & 0,14 \\
\hline 17 & Produk dikenal oleh para konsumen & 0,045 & 3 & 0,14 \\
\hline 18 & Harga Bersaing & 0,05 & 3,7 & 0,19 \\
\hline 19 & $\begin{array}{l}\text { Produk Memenui Standart ISO (International } \\
\text { Organization For Standardization) }\end{array}$ & 0,045 & 3,6 & 0,16 \\
\hline 20 & $\begin{array}{l}\text { Tingkat minat konsumen meningkat ketika } \\
\text { banyaknya pembangunan infrastruktur }\end{array}$ & 0,045 & 3,7 & 0,17 \\
\hline \multicolumn{5}{|c|}{ Finance } \\
\hline & $\begin{array}{l}\text { Pencatatan yang sistematis menghindari } \\
\text { kerugian }\end{array}$ & 0,042 & 3,5 & 0,15 \\
\hline & Pengeluaran biaya terkendali & 0,048 & 2,9 & 0,14 \\
\hline & Total & 1 & & 3,15 \\
\hline
\end{tabular}

Sumber: Data Diolah, 2020 
Lampiran 2. Kuesioner Internal Faktor Analisis Strategi untuk Mengetahui Kelemahan

\begin{tabular}{|c|c|c|c|c|}
\hline & Faktor Strategi & $\begin{array}{l}\text { Bobot } \\
\text { (B) }\end{array}$ & $\begin{array}{l}\text { Rating } \\
(\mathrm{R})\end{array}$ & $\begin{array}{c}\text { Skor } \\
(\mathrm{S}=\mathrm{B} \times \mathrm{R})\end{array}$ \\
\hline \multicolumn{5}{|c|}{ MSDM } \\
\hline 1 & Kedisiplinan karyawan & 0,065 & -2 & $-0,13$ \\
\hline 2 & Minimnya pengalaman pegawai baru & 0,061 & -2 & $-0,12$ \\
\hline 3 & Kompetensi SDM yang lemah & 0,065 & -2 & $-0,13$ \\
\hline 4 & Lingkungan kerja yang kurang baik & 0,061 & $-1,9$ & $-0,12$ \\
\hline \multicolumn{5}{|c|}{ Kurangnya training untuk meningkatkan kualitas } \\
\hline & SDM & 0,067 & $-1,9$ & $-0,13$ \\
\hline & Rendahnya tingkat Pendidikan karyawan & 0,058 & $-1,9$ & $-0,11$ \\
\hline \multicolumn{5}{|c|}{ Operasional } \\
\hline 7 & Luas area kantor operasional & 0,07 & $-1,6$ & $-0,11$ \\
\hline 8 & Biaya produksi mesin semakin mahal & 0,057 & -2 & $-0,11$ \\
\hline 9 & Pengetahuan terhadap SOP relative rendah & 0,065 & $-2,1$ & $-0,14$ \\
\hline 10 & Pencapaian target produksi & 0,061 & $-2,3$ & $-0,14$ \\
\hline & Fasilitas masih kurang & 0,07 & -2 & $-0,14$ \\
\hline \multicolumn{5}{|c|}{ Produk } \\
\hline 12 & $\begin{array}{l}\text { Volume penjualan terkadang mengalami } \\
\text { penurunan }\end{array}$ & 0,057 & $-2,2$ & $-0,13$ \\
\hline 13 & Adanya keterlambatan dalam pengerjaan kontruksi & 0,058 & $-2,5$ & $-0,15$ \\
\hline & $\begin{array}{l}\text { Kualitas material dari supplier tidak sesuai dengan } \\
\text { standart }\end{array}$ & 0,061 & $-2,3$ & $-0,14$ \\
\hline \multicolumn{5}{|c|}{ Finance } \\
\hline 15 & Cash flow & 0,061 & $-2,2$ & $-0,13$ \\
\hline 16 & $\begin{array}{c}\text { Pembayaran konsumen melalui transfer dan } \\
\text { berdasarkan tahap kemajuan pekerjaan } \\
\text { Total }\end{array}$ & $\begin{array}{c}0,063 \\
1\end{array}$ & $-2,2$ & $\begin{array}{l}-0,14 \\
-2,07\end{array}$ \\
\hline
\end{tabular}

Sumber: Data Diolah, 2020 
Lampiran 3. Kuesioner Eksternal Faktor Analisis Strategi untuk Mengetahui Peluang (Opportunities)

\begin{tabular}{|c|c|c|c|c|}
\hline \multicolumn{2}{|r|}{ Faktor Strategi } & $\begin{array}{l}\text { Bobot } \\
(\mathrm{B})\end{array}$ & $\begin{array}{l}\text { Rating } \\
(\mathrm{R})\end{array}$ & $\begin{array}{c}\text { Skor } \\
(\mathrm{S}=\mathrm{B} \times \mathrm{R})\end{array}$ \\
\hline \multicolumn{5}{|c|}{ Lingkungan Makro } \\
\hline 1 & $\begin{array}{l}\text { Perekonomian perusahaan mulai membaik dan tumbuh } \\
\text { stabil }\end{array}$ & 0,081 & 3 & 0,24 \\
\hline 2 & $\begin{array}{l}\text { Kebijakan perekonomian perusahaan yang mulai } \\
\text { diperbaiki pemerintah }\end{array}$ & 0,073 & 3,2 & 0,23 \\
\hline 3 & $\begin{array}{l}\text { Kebijakan pemerintah untuk membangun infruktur } \\
\text { (Bandara) }\end{array}$ & 0,079 & 3 & 0,24 \\
\hline 4 & Sistem politik di Indonesia yang mulai terarah & 0,077 & 2,6 & 0,2 \\
\hline 5 & Penambahan penduduk yang semakin meningkat & 0,077 & 3,3 & 0,25 \\
\hline 6 & Jumlah penumpang pesawat yang semakin meningkat & 0,075 & 3 & 0,23 \\
\hline & $\begin{array}{l}\text { Adanya proyek nasional sehingga meningkatkan } \\
\text { pembelian alat-alat conveyer }\end{array}$ & 0,079 & 3 & 0,24 \\
\hline & $\begin{array}{l}\text { Sarana pemesanan melalui tender dengan perusahaan } \\
\text { yang berkualifikasi }\end{array}$ & 0,073 & 3,5 & 0,26 \\
\hline & $\begin{array}{l}\text { Mengikuti Perkembangan alat conveyor yang semakin } \\
\text { canggih }\end{array}$ & 0,077 & 2,8 & 0,22 \\
\hline & gkungan Mikro & & & \\
\hline 10 & Petunjuk lokasi yang mudah dicari & 0,081 & 3 & 0,24 \\
\hline 11 & Adanya hubungan baik dengan pelanggan & 0,077 & 3,4 & 0,26 \\
\hline 12 & Jumlah pelanggan tetap meningkat & 0,075 & 3,2 & 0,24 \\
\hline 13 & Kebersihan dan kenyamanan ruangan yang sangat baik & 0,075 & 2,9 & 0,22 \\
\hline
\end{tabular}

Sumber: Data Diolah, 2020

Lampiran 4. Kuesioner Eksternal Faktor Analisis Strategi untuk Mengetahui Ancaman (Threats)

\begin{tabular}{|c|c|c|c|c|}
\hline & Faktor Strategi & $\begin{array}{l}\text { Bobot } \\
\text { (B) }\end{array}$ & $\begin{array}{l}\text { Rating } \\
\text { (R) }\end{array}$ & $\begin{array}{c}\text { Skor } \\
(S=B \times R)\end{array}$ \\
\hline \multicolumn{5}{|c|}{ MSDM } \\
\hline 1 & Tuntutan upah, gaji atau bonus & 0,097 & $-2,2$ & $-0,21$ \\
\hline 2 & Adanya kesetresan kerja & 0,088 & $-2,2$ & $-0,19$ \\
\hline 3 & Tuntutan tunjangan-tunjangan & 0,093 & $-2,1$ & $-0,2$ \\
\hline 4 & Tenaga ahli keluar dan masuk pekerjaan & 0,088 & $-2,2$ & $-0,19$ \\
\hline \multicolumn{5}{|c|}{ Lingkungan Makro } \\
\hline 5 & Produk luar negeri yang mulai masuk didalam negeri & 0,088 & -2 & $-0,18$ \\
\hline 6 & Tingkat inflasi yang semakin tinggi & 0,091 & -2 & $-0,18$ \\
\hline 7 & Tidak stabilnya mata uang rupiah terhadap mata uang asing & 0,093 & $-2,1$ & $-0,2$ \\
\hline & $\begin{array}{l}\text { Kebijakan pemerintah dalam hal untuk mengurangi subsidi } \\
\text { masyarakat dalam hal listrik, BBM dan lain-lain }\end{array}$ & 0,088 & $-1,6$ & $-0,14$ \\
\hline \multicolumn{5}{|c|}{ Lingkungan Mikro } \\
\hline 9 & Harga bahan baku yang tidak stabil & 0,088 & $-2,4$ & $-0,21$ \\
\hline 10 & Persaingan harga kompetitor & 0,093 & $-2,5$ & $-0,23$ \\
\hline 11 & Perubahan perkembangan teknologi & 0,093 & $-2,4$ & $-0,22$ \\
\hline & Total & 1 & & $-2,15$ \\
\hline
\end{tabular}

Sumber: Data Diolah, 2020 